\title{
СУТНІСТЬ І СТРУКТУРА СФОРМОВАНОСТІ ПРОФЕСІЙНОГО МОВЛЕННЯ СТУДЕНТІВ - МЕДИЧНИХ СЕСТЕР У ПРОЦЕСІ ФАХОВОЇ ПІДГОТОВКИ
}

\author{
В. Й. Кульчицький \\ Тернопільський національний медичний університет \\ імені І. Я. Горбачевського МОЗ Украӥни
}

У статті проаналізовано сутність і структуру сформованості професійного мовлення студентів медичних сестер у процесі фахової підготовки.

\section{THE ESSENCE AND STRUCTURE OF THE FORMATION OF PROFESSIONAL LANGUAGE OF STUDENTS - NURSES IN THE PROCESS OF PROFESSIONAL TRAINING}

\author{
V. Y. Kulchytskyj
}

\section{Horbachevsky Ternopil National Medical University}

The article analyzes the essence and structure of the formation of professional speech of students - nurses in the process of professional training.

Вступ. Тема культури спілкування, професійного мовлення фахівців медичної галузі надзвичайно широка, складна та делікатна. Нині накопичено певний теоретичний і експериментальний матеріал про формування професійного мовлення майбутніх спеціалістів різних галузей. Науковці по-різному підходять до вирішення даної проблеми, пропонуючи систему різноманітних завдань, педагогічні технології, розробляючи лінгвістичні напрямки формування мовленнєво-професійної культури студентів навчальних закладів. Проте далеко не в кожному науковому дослідженні розглядають сутність та структурні складові сформованості професійного мовлення.

Основна частина. На мою думку, перш ніж формувати певні уміння, навички, тим більше професійне мовлення майбутніх фахівців медичних закладів, необхідно встановити сутність й проаналізувати ознаки професійного мовлення, виявити у студентів рівень володіння мовними знаннями, мовленнєвими уміннями та навичками, визначити, що саме потрібно вдосконалювати.

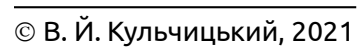

Дослідження в галузі психолінгвістики (М. Жинкін, О. Леонтьєв, О. Лурія) дають підстави твердити, що для повноцінного спілкування людина повинна мати цілу низку вмінь: по-перше, швидко і правильно орієнтуватися під час спілкування; по-друге, правильно спланувати своє мовлення; по-третє, знайти адекватні засоби для передачі його змісту. Сам мовленнєвий процес учені визначають як творчий, оскільки одну і ту саму думку різні люди передають по-різному [1].

На думку В. Момота, високий рівень культури професійного мовлення забезпечується комплексом умінь, найголовніші серед яких такі: організаторські - вміння організувати процес спілкування, спираючись на знання ситуації, мотиву й мети спілкування, на правильне розуміння партнера, встановлення контакту; вміння викликати й підтримувати інтерес до процесу спілкування, поступово розв'язуючи одне за одним поставлені завдання; інформативні - уміння викласти інформацію за темою спілкування в монологічній або діалогічній формі, узгоджуючи інформативну насиченість повідомлення доступним для адресата лексичним мате- 
ріалом, синтаксичними конструкціями, інтонаційним оформленням; перцептивні - уміння словом і ділом впливати на партнерів, переконувати їх, схиляти до свого погляду; контрольно-стимулювальні - вміння оцінювати діяльність співрозмовника на кожному етапі спілкування у такій формі, яка сприяє прагненню до подальшого спілкування, а також уміння самооцінки, аналізу власної мовленнєвої діяльності. Ці вміння, як підкреслює дослідник, взаємодіють в акті спілкування, забезпечуючи здатність спеціаліста до ділового спілкування [2].

Н. Тоцька вважає, що основою мовленнєвої компетенції майбутнього фахівця $є$ такі комунікативні уміння:

- уміння вести діалог, дотримуючись вимог мовного етикету в різних життєвих ситуаціях (у дружньому колі, у ситуації безпосереднього спілкування на зборах, засіданнях, ділових зустрічах, розмовах по телефону);

- уміння створювати усні монологічні висловлювання (виступати з повідомленням, доповіддю; поділитися в колі знайомих побаченим, почутим, пережитим; висловити своє ставлення до обговорюваного питання; дати певні роз'яснення);

- уміння адекватно сприймати на слух діалог і монолог, що передбачає зосередження уваги на осмисленні висловлювання (проблеми, фактів, доказів головного і другорядного, логіки викладу), використання різних прийомів фіксації почутого (запис ключових слів, плану висловлювання, статистичних даних) залежно від комунікативного завдання (участь у дискусії, передача інформації іншому, використання ії̈ у своїй роботі);

- уміння створювати письмові тексти різних стилів і типів, різних жанрів;

- уміння користуватися різними видами читання [3].

Узагальнюючи, можна зауважити, що, на думку вчених, зміст мовленнєвої компетенції являє собою узгоджену єдність усіх компонентів, які створюють ситуації спілкування: соціальні й комунікативні ролі; місця, де відбувається спілкування; теми й плани їх розкриття, функції мови й інтенціональний план висловлювання [4]. Об'єднуючи в збалансоване ціле ці різні аспекти використання мови, саме комунікативна компетенція адекватно й повно відображає картину спілкування особистості в певному професійному колективі, з конкретною людиною, сприяє реалізації усіх функцій мовлення.
Цілком очевидно, що одних знань недостатньо для реалізації мовленнєвої діяльності, необхідно вміти їх застосовувати. Як слушно зауважує Л. Путляєва, про якість підготовки спеціаліста судять не за кількістю й рівнем знань як таких і не за розвитком абстрактного мислення, а за здатністю застосовувати ці знання на практиці, використовувати мислення для вирішення нових професійних завдань [5].

У контексті наукового дослідження варто зауважити, що професійне мовлення медичних сестер повинно відповідати нормам сучасної української літературної мови. Мова з багатьма їі функціями (комунікативною, номінативною, культуроносною, мислетворчою та ін.) забезпечує належний рівень грамотності носіїв певної професії, формує їхнє вміння спілкуватися в усіх сферах комунікації - у ділових відносинах, у науці, освіті, культурі, економіці тощо. Особливо це стосується медичних працівників, мовлення яких має бути якісним.

Рівень їхньої культури професійного мовлення залежить від змісту й послідовності, точності й доречності висловлювання, багатства словника, досконалого володіння умінням поєднувати слова в реченні, будувати різноманітні структури, активно застосовувати норми літературної мови.

Отже, для того, щоб задовольнити потреби функціонування, мовлення медичних працівників повинно мати певні комунікативні якості - правильність, точність, логічність, виразність, лаконічність, доречність. Основною комунікативною якістю мовлення дослідники (Б. Головін, М. Ілляш, М. Михайлов, М. Пентилюк, М. Пилинський) вважають правильність, оскільки саме правильність мовлення забезпечує його взаєморозуміння та єдність [6].

Правильним $\epsilon$ професійне мовлення спеціаліста, який володіє фаховою термінологією на різних рівнях мовної системи. Термінологія медицини - одна з найскладніших терміносистем сучасної науки. Це відкрита система, в якій спостерігається постійний процес заміни одних лексем іншими, виникнення нових термінів. Знання фахової термінології $\epsilon$ обов'язковою умовою сформованості культури професійного мовлення фахівця медичної галузі, оскільки без цього не можна грамотно зафіксувати результати обстеження, виписати рецепт, оформити медичний документ.

Таким чином, на основі аналізу наукової літератури в структурі професійного мовлення медичних працівників, зокрема медичних сестер, можемо ви- 
ділити такі компоненти: когнітивний - знання норм сучасної української літературної мови (орфоепічних, акцентних, лексичних, синтаксичних, морфологічних, стилістичних, орфографічних тощо), фахової термінології; комунікативно-операційний - уміння використовувати мовні засоби відповідно до мети, умов, ситуації спілкування; володіння базовими професійно-мовленнєвими уміннями, необхідними для медичної галузі; експресивний - володіння екстралінгвістичними засобами спілкування (мелодика, фразовий наголос, паузи, ритм, тембр, темп і сила голосу).

До показників сформованості когнітивного компонента професійного мовлення медичних сестер у процесі фахової підготовки належать: знання норм сучасної української літературної мови; володіння медичною термінологією та професійною лексикою; знання особливостей усного й писемного професійного мовлення медичної галузі.

Проте одних знань недостатньо для досконалого володіння мовою, потрібно вміти їх використовувати відповідно до ситуації мовлення, до реальних умов професійної діяльності.

На думку Р. Грабовської, особливості мови людини, фахівця безпосередньо пов'язані з виконанням ними соціальної ролі, з рівнем культури. Широта відбору лексики, уміння знайти вдале і потрібне слово для вираження певного стану - все це компоненти соціального портрету людини [7].

У зв'язку з цим, одним із складників професійного мовлення медичних сестер $є$ комунікативно-операційний складник, який визначається самоусвідомленням мовної особистості. Вона зароджується і розвивається там, де носіям національної літературної мови не байдуже як вони говорять і пишуть, як сприймається їхня мова в різних суспільних середовищах, а також у контексті інших мов [8].

Сформованість комунікативно-операційного компонента професійного мовлення майбутніх медичних працівників відображають такі показники: уміння використовувати лексичне багатство української мови; володіння культурою конструктивного діалогу та полілогу; уміння сприймати, відтворювати готові та створювати наукові фахові тексти, застосовувати професійну термінологію у різноманітних комунікативних процесах; володіння прийомами підготовки і виголошення публічного виступу; уміння оформляти ділові папери, які використовують в медичній галузі; уміння помічати як чужі, так і власні мовленнєві не- доліки; прагнення досягти мовленнєвої майстерності; рівень задоволення індивідуума якістю власної мовленнєвої культури. Володіння цими уміннями забезпечує реалізацію однієї з основних комунікативних якостей мовлення - правильності.

Таким чином, для тактовних, інтелігентних медичних працівників, зокрема медичних сестер, під час розмови з колегами, пацієнтами, їхніми родичами має велике значення не тільки зміст їх слів, але й форма, інтонація, вираз обличчя, врахування індивідуальних особливостей людей. Без цього не можна говорити про високу культуру професійного мовлення медичних працівників, про рівень сформованості її експресивного компонента, показниками якого $€$ уміння використовувати тон, силу голосу, виражальні можливості інтонації.

Для визначення сформованості комунікативної культури у студентів вищих медичних навчальних закладів О. Уваркіна виділила чотири рівні: елементарний, достатній, базовий і досконалий [9].

Для визначення сформованості професійного мовлення у студентів - медичних сестер ми виділили три рівні: інтуїтивний (низький), репродуктивний (середній), творчий (високий).

Інтуїтивний (низький) рівень характеризується відсутністю системних знань, бідним словниковим запасом студента, частими випадками неправильного слововживання, фрагментарним відтворенням мовного матеріалу, великою кількістю орфографічних і пунктуаційних помилок, значним порушенням орфоепічних і акцентних норм літературної мови, невмінням реалізовувати мовленнєві дії, характерні для медичної галузі. Характерними є низька мовна свідомість, відсутність прагнення удосконалювати власне мовлення.

Репродуктивний (середній) рівень визначається знаннями граматики й стилістики здебільшого в теоретичному аспекті, здатністю з помилками й неточностями дати визначення понять; відхиленнями від акцентних, орфоепічних, орфографічних, пунктуаційних, лексичних норм літературної мови; незначною невідповідністю мовних засобів меті й ситуації мовлення. Проблеми з налагодженням спілкування виникають в основному через недостатній словниковий запас.

Творчий (високий) рівень сформованості культури професійного мовлення студентів - медичних сестер передбачає наявність глибоких і міцних знань 3 мови, їх застосування в різних ситуаціях, при цьому 
студент може припускатися незначних огріхів як в усному, так і в писемному висловлюванні; сформованість навичок оформлення ділових паперів, що використовують в медичній галузі, навичок монологічного висловлювання, вміння вести діалог; наявність естетичних зовнішніх засобів, техніки та культури мовлення; свідоме ставлення до мови взагалі, бажання вдосконалювати власне мовлення.

Висновки. Окреслені компоненти, показники та рівні дадуть нам можливість визначити основні складові методики формування професійного мовлення майбутніх медичних сестер у процесі фахової підготовки.

\section{СПИСОК ЛІТЕРАТУРИ}

1. Бабенко О. Плекаймо мовну особистість / О. Бабенко // Дивослово. - 2004. - № 4. - С. 56-59.

2. Момот В. М. Формування професійно зорієнтованого мовлення у студентів технікумів і коледжів технічного профілю : дис. ... канд. пед. наук / В. М. Момот. - К., 2002. - 185 c.

3. Тоцька Н. Л. Формування професійно зумовленого мовлення студентів технічного ВНЗ (з технологічних спеціальностей легкої промисловості) : дис. ... канд. пед. наук / Н. Л. Тоцька. - Херсон, 2001. - 215 с.

4. Медвідь А. М. Практикум з ділової української мови / А. М. Медвідь. - К. : Здоров'я, 2002. - 224 с.

5. Мороз О. Г. Педагогіка і психологія вищої школи : навчальний посібник для молодих викладачів, аспі-
Основою професійного мовлення $\epsilon$ наявність в особистості: мовної компетенції - знання норм літературної мови; сформованих механізмів сприйняття й продукування, закладених у поняття мовленнєвої компетенції; комунікативної компетенції - спроможності вибирати й реалізовувати програми мовленнєвої поведінки залежно від здатності людини орієнтуватися в різноманітних ситуаціях, тобто їі уміння оцінювати ситуації, враховуючи тему, завдання, комунікативні установки, що виникають в учасників до й під час бесіди.

рантів і майбутніх магістрів / О. Г. Мороз, О. С. Падалка, В. І. Юрченко ; за заг. ред. О. Г. Мороза. - К. : КНПУ, 2003. - 268 c.

6. Головащук С. І. Українське літературне слововживання : словник-довідник / С. І. Головащук. - К. : Вища школа, 1995. - 319 c.

7. Грабовська Т. Формування позитивної мотивації діяльності студентів / Т. Грабовська, О. Киричук // Рідна школа. - 2002. - № 4. - С. 12-14.

8. Кочан І. М. Культура рідної мови / І. М. Кочан, А. С. Токарська. - Львів : Світ, 1996. - 232 с.

9. Гуманізація та гуманітаризація професійної освіти : науково-методичний збірник. - К. : ІСДОІ, 1995. - 160 с. 